\title{
RESPONSE OF THE SLOW-GROWING MISTLETOE FIG (FICUS DELTOIDEA JACK.) PLANT TO FERTILIZATION TREATMENTS AND GROWTH ACTIVATOR 1. THE LIQUID COMMERCIAL PRODUCT OF NITROPHENOLATES
}

\author{
Amal S. El-Fouly; Azza M. Abdel-Moneim and Hanan E. Ibrahim
}

Ornamental Plants and Landscape Gardening Res. Dept., Hort. Res. Inst., ARC, Giza, Egypt.

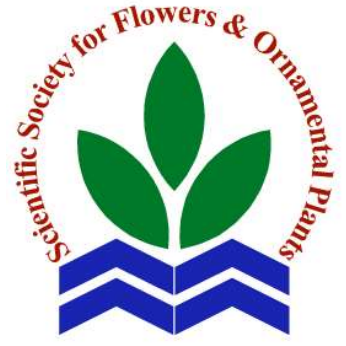

Scientific J. Flowers \& Ornamental Plants, 1(1):17-24 (2014).

Received:

$26 / 1 / 2014$

Revised by:

Prof. Dr. E.S. Nofal, Kafr El-Sheikh Univ.

Prof. Dr. B.M. Weheda, Hort. Res. Inst., ARC.
ABSTRACT: Two pot experiments were conducted under plastic house (temperature, R.H. and light intensity inside the plastic house during the course of study were ranged between: $24.5-38.7^{\circ} \mathrm{C}, 46.6-$ $81.5 \%$ and 500-600 lux, respectively) at the nursery of Hort. Res. Int., ARC, Giza, Egypt during 2012 and 2013 seasons to study the effect of a liquid commercial product which contains $1 \mathrm{~g} / \mathrm{l}$ sodium 5nitroguaiacolate $+2 \mathrm{~g} / 1$ sodium ortho-nitrophenolate $+3 \mathrm{~g} / 1$ sodium para-nitrophenolate when added individually or in combination, monthly for 5 repeats during the growing season, either as a foliar spray or as a soil drench at the rates of $0.25,0.50$ and $1.00 \mathrm{~cm}^{3} / 1$ on growth performance and chemical composition of the slow-growing Ficus deltoidea Jack. foliage pot-plant.

The results of the experiments showed that all vegetative and root growth parameters were improved in response to the various treatments used in this work with the different significance levels relative to an untreated control in both seasons. Spraying the foliage with the low and medium levels gave, to some extent better results than the high level, while that was true for soil drench method when nitrophenolates were drenched at the low rate. Increasing level of nitrophenolates to $1.0 \mathrm{~cm}^{3} / 1$ did not cause any additional improvement in growth, whereas combining between the two application methods clearly enhanced growth. So, the supremacy was for the combination of foliar spray and soil drench at $1.0 \mathrm{~cm}^{3} / 1$ for each, as this combination gave the highest means in most cases of the two seasons. A similar trend was also attained concerning the leaf content of chlorophylls a and b, carotenoids , N, P, K, Fe, Zn and Mn, as these constituents were higher in the leaves of treated plants by the two methods of application at the high level for both $\left(1.0 \mathrm{~cm}^{3} / 1\right)$ than in the leaves of plants treated with other treatments.

Hence, it is recommended to apply the liquid commercial product of nitrophenolates to mistletoe fig plant, monthly for 5 times during the growing season, as a foliar spray and soil drench at the rate of 1.0 $\mathrm{cm} 3 / 1$ for each to attain better growth performance and chemical composition.

Key word: Fertilization, nitrophenolates, ornamental plants, Ficus deltoidea Jack. 


\section{INTRODUCTION}

Among slowly grow ornamental plant may be mistletoe fig ( Ficus deltoidea Jack.) that belongs to Fam. Moraceae. It is a largely glabrous shrub or small tree up to $7 \mathrm{~m}$ height, characterized with its deltoid leaves (Huxley et al., 1992). When grow as a foliage potplant, its roots are restricted inside the small size of pot, and so it can not take its requirements of water and nutrients augmenting its slow growth rate and not reaching the suitable size for marketing except after a long period.

For decades plant growth activators have been used to improve the growth and yield of various crops. Among which, the commercial products called: chaperone, Asahi SL, Atonik, Lena tonik, ....etc., that contain some active ingredients, termed nitrophenolates, which are found naturally in plants and stimulate growth by altering the activity of specific antioxidant enzymes, such as superoxide dismutase (SOD), catalase (CAT) and peroxidase (POX) (Djanaguiraman et al., 2004). Several reports in the literature proved the role of these compound in enhancing growth and yield. In this regard, Gornik and Grzesik (2002) found that applying of Asahi SL, 3 times during flowering of China aster (Callistephus chinensis) at 0.2 or $0.4 \%$ brought about an increase in No. flowers/plant, seed yield, germination and metabolic activity without modifying vegetative growth. Using the chemical earlier, before flowering, had detrimental effect on flower yield and quality, although it stimulated vegetative growth. Xiao-yue (2008) indicated that spraying 7 repeats of $1.4 \%$ sodium orthonitrophenolate + sodium para-nitrophenolate $+\quad$ sodium5-nitroguaiacolate could significantly increase diameter, weight of simple fruit, yield of simple tree and fruit quality of Camellia oleifera compared with the control. Zhanga et al. (2010) postulated that sodium-nitrophenolate increased plant height, basal stem diameter, aboveground biomass, seed yield and harvest index of alfalfa plant (Medicago sativa $\mathrm{L}$.).
Similar observations were also demonstrated by Sharma et al. (1990) on soybean, Jadhav et al. (1990) on pearl millet (Pennisetum americanum), Bynum et al. (2007), Gencsoylu (2009) and Singh et al. (2010) on cotton, Cai-lian et al. (2010) on soybean, and Ogorek et al. (2011) who pointed out that growth rate of Fusarium spp. was different in response to the different concentrations of Asahi SL biostimulator. The extent of the growth inhibition was directly proportional to the concentration of Asahi SL in culture medium.

The aim of the current experiment was to determine the effect of application method and level of sodium-nitrophenolate and its composition on growth and quality of mistletoe fig plant.

\section{MATERIALS AND METHODS}

Two pot experiments were consummated under plastic house at the nursery of Hort. Res. Inst., ARC, Giza, Egypt throughout 2012 and 2013 seasons to study the individual or combined effect of $\mathrm{Na}$ nitrophenolate and its ingredients at various levels on growth and chemical composition of mistletoe fig as foliage pot-plant.

Therefore, uniform, six-months-old transplants of mistletoe fig (Ficus deltoidea Jack.) were planted on mid of March for both seasons in 20-cm-diameter plastic pots (one transplant/pot) filled with about $2.5 \mathrm{~kg}$ of sand + clay + peatmoss mixture at equal volumes $(1: 1: 1, \mathrm{v} / \mathrm{v} / \mathrm{v})$. The physical and chemical properties of the used sand and clay, as well as those of peatmoss are shown in Tables (a) and (b), respectively. During the course of this work, air temperature and R.H. inside the plastic house ranged between $22.5-37.5^{\circ} \mathrm{C}$ and $50-75 \%$, respectively. Irrigation and other agricultural practices necessary for such plantation were done whenever needed.

The pots were arranged in a completely randomized design (Mead et al., 1993) with 3 replicates, where each replicate contained 5 pots. 
Table a. Some physical and chemical properties of the used sand and clay during 2012 and 2013 seasons.

\begin{tabular}{|c|c|c|c|c|c|c|c|c|c|c|c|c|c|c|}
\hline \multirow{2}{*}{ 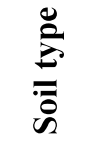 } & \multicolumn{4}{|c|}{ Particle size distribution (\%) } & \multirow{2}{*}{ S.P } & \multirow{2}{*}{$\begin{array}{c}\text { E.C. } \\
(\mathrm{ds} / \mathrm{m})\end{array}$} & \multirow{2}{*}{ pH } & \multicolumn{4}{|c|}{ Cations (meq/l) } & \multicolumn{3}{|c|}{ Anions (meq/l) } \\
\hline & $\begin{array}{c}\text { Coarse } \\
\text { sand }\end{array}$ & $\begin{array}{l}\text { Fine } \\
\text { sand }\end{array}$ & Silt & Clay & & & & $\mathbf{C a}^{++}$ & $\mathbf{M g}^{++}$ & $\mathrm{Na}^{+}$ & $\mathbf{K}^{+}$ & $\mathrm{HCO}_{3}^{-}$ & $\mathrm{Cl}^{-}$ & $\mathrm{SO}_{4}^{--}$ \\
\hline Clay & 7.46 & 16.75 & 34.53 & 40.89 & 41.76 & 2.18 & 8.33 & 16.93 & 9.33 & 20.44 & 0.37 & 3.82 & 1.46 & 41.79 \\
\hline Sand & 18.72 & 71.28 & 4.76 & 5.34 & 21.83 & 1.58 & 8.20 & 2.65 & 2.48 & 21.87 & 0.78 & 3.85 & 13.00 & 10.93 \\
\hline
\end{tabular}

Table b. Physical and chemical analysis of the used peatmoss in the two seasons.

\begin{tabular}{|c|c|c|c|}
\hline Organic matter.. & $90-95 \%$ & $\mathbf{P} \ldots \ldots$ & $0.23 \%$ \\
\hline Ash................. & $5-10 \%$ & $\mathbf{K} \ldots \ldots$ & $1.77 \%$ \\
\hline Density (Vol. Dry) ......... & $80-90 \mathrm{mg} / \mathrm{l}$. & Fe............... & $421 \mathrm{ppm}$ \\
\hline pH value................... & 3.4 & Mn ................ & $27 \mathrm{ppm}$ \\
\hline $\begin{array}{l}\text { Water relation capacity... } \\
\text { Salinity } \ldots \ldots \ldots \ldots \ldots \ldots \ldots \ldots \\
\mathbf{N} \ldots \ldots \ldots \ldots \ldots \ldots \ldots \ldots \ldots \ldots\end{array}$ & $\begin{array}{l}60-75 \% \\
0.3 \mathrm{~g} / 1 \\
1.09 \%\end{array}$ & $\mathrm{Zn} \ldots \ldots \ldots \ldots \ldots$ & $41 \mathrm{ppm}$ \\
\hline
\end{tabular}

One month later (on April, $15^{\text {th }}$ ), the transplants received the different treatments as follows:

1. No. treatment, (control).

2. A liquid commercial product which contains $1 \mathrm{~g} / 1$ sodium 5-nitroguaiacolate $\left(\mathrm{NaC}_{7} \mathrm{H}_{6} \mathrm{NO}_{4}\right)+2 \mathrm{~g} / 1$ sodium orthonitrophenolate $\left(\mathrm{NaC}_{6} \mathrm{H}_{4} \mathrm{NO}_{3}\right)+3 \mathrm{~g} / \mathrm{l}$ sodium para-nitrophenolate $\left(\mathrm{NaC}_{6} \mathrm{H}_{4} \mathrm{NO}_{3}\right)$, manufactured by Lena Tarim Co., Ltd., Sokak No. 63 Ostim, Ankara, Turkey, was added monthly for 5 times during the active growing season, either as a foliar spray or as a soil drench at the rates of $0.25,0.50$ and $1.00 \mathrm{~cm}^{3} / 1$.

3. Three combined treatments were formed as follows:

- Foliar spray + soil drench at $0.25 \mathrm{~cm}^{3} / 1$ for each.

- Foliar spray + soil drench at $0.50 \mathrm{~cm}^{3} / 1$ for each.

- Foliar spray + soil drench at $1.00 \mathrm{~cm}^{3} / 1$ for each.

At the end of the experiment (on mid of October for each season), the following data were recorded: plant height $(\mathrm{cm})$, number of leaves and branches/plant, root length $(\mathrm{cm})$ and fresh and dry weights of leaves and roots (g). In fresh leaf samples taken from the middle part of the plants, photosynthetic pigments (chlorophyll a, b and carotenoids, $\mathrm{mg} / \mathrm{g}$ f.w.) were assessed according to the method of Saric et al. (1976), while in dry ones, the percentages of nitrogen $(\mathrm{N})$, phosphorus $(\mathrm{P})$ and potassium $(\mathrm{K})$, as well as the content of ferrous $(\mathrm{Fe})$, zinc $(\mathrm{Zn})$ and manganese (Mn) (mg/100g d.w.) were measured using the methods described by A.O.A.C. (1995).

Data were then tabulated and subjected to analysis of variance using SAS program (1994) and Duncan's Multiple Range Test (Duncan, 1955) was used to compare among means of the different treatments.

\section{RESULTS AND DISCUSSION}

Effect of nitrophenolate and its composition on:

\section{1- Vegetative and root growth traits:}

It is clear from data averaged in Tables (1 and 2) that means of all vegetative and root growth parameters were improved in response to the various treatments used in this study with different significant levels when compared to those of control in the two seasons. 
Amal S. El-Fouly et al.

Table 1. Effect of application method and level of plant growth regulator on some vegetative growth traits of Ficus deltoidea Jack. plant during 2012 and 2013 seasons.

\begin{tabular}{lcccccccc}
\hline \multicolumn{1}{c}{$\begin{array}{c}\text { Application method } \\
\text { and level }\left(\mathbf{c m}^{\mathbf{3}} / \mathbf{l}\right)\end{array}$} & \multicolumn{2}{c}{ Plant height (cm) } & \multicolumn{2}{c}{ No. leaves/plant } & \multicolumn{3}{c}{ No. branches/plant } & \multicolumn{2}{c}{ Root length (cm) } \\
\hline Control & $\mathbf{2 0 1 2}$ & $\mathbf{2 0 1 3}$ & $\mathbf{2 0 1 2}$ & $\mathbf{2 0 1 3}$ & $\mathbf{2 0 1 2}$ & $\mathbf{2 0 1 3}$ & $\mathbf{2 0 1 2}$ & $\mathbf{2 0 1 3}$ \\
\hline Foliar spray at 0.25 (A) & $27.67 \mathrm{c}$ & $27.00 \mathrm{~d}$ & $15.69 \mathrm{f}$ & $16.27 \mathrm{f}$ & $2.33 \mathrm{~d}$ & $2.00 \mathrm{~d}$ & $22.00 \mathrm{e}$ & $23.10 \mathrm{e}$ \\
Foliar spray at 0.50 (B) & $30.70 \mathrm{ba}$ & $27.36 \mathrm{~cd}$ & $22.33 \mathrm{~d}$ & $22.30 \mathrm{~d}$ & $3.67 \mathrm{c}$ & $3.33 \mathrm{~cd}$ & $43.20 \mathrm{~b}$ & $43.21 \mathrm{bc}$ \\
Foliar spray at 1.00 (C) & $28.68 \mathrm{bc}$ & $28.00 \mathrm{c}$ & $27.31 \mathrm{c}$ & $27.38 \mathrm{c}$ & $4.00 \mathrm{c}$ & $4.00 \mathrm{c}$ & $38.33 \mathrm{c}$ & $37.80 \mathrm{c}$ \\
Soil drench at 0.25 (D) & $30.33 \mathrm{~b}$ & $30.56 \mathrm{ba}$ & $23.00 \mathrm{~d}$ & $23.76 \mathrm{~d}$ & $4.70 \mathrm{~b}$ & $4.76 \mathrm{bc}$ & $30.10 \mathrm{~d}$ & $28.33 \mathrm{de}$ \\
Soil drench at 0.50 (E) & $28.67 \mathrm{bc}$ & $28.76 \mathrm{bc}$ & $16.90 \mathrm{f}$ & $16.30 \mathrm{f}$ & $4.00 \mathrm{c}$ & $4.00 \mathrm{c}$ & $31.00 \mathrm{~d}$ & $30.67 \mathrm{~d}$ \\
Soil drench at 1.00 (F) & $26.30 \mathrm{~d}$ & $26.68 \mathrm{~d}$ & $19.30 \mathrm{e}$ & $19.71 \mathrm{e}$ & $4.68 \mathrm{~b}$ & $4.33 \mathrm{cb}$ & $24.26 \mathrm{e}$ & $24.33 \mathrm{e}$ \\
A+D & $30.33 \mathrm{~b}$ & $29.67 \mathrm{~b}$ & $41.70 \mathrm{a}$ & $40.68 \mathrm{a}$ & $7.31 \mathrm{a}$ & $7.33 \mathrm{a}$ & $45.80 \mathrm{~b}$ & $46.67 \mathrm{~b}$ \\
B+E & $31.70 \mathrm{ab}$ & $31.50 \mathrm{ab}$ & $39.33 \mathrm{a}$ & $39.72 \mathrm{a}$ & $4.67 \mathrm{~b}$ & $5.00 \mathrm{~b}$ & $37.69 \mathrm{c}$ & $38.00 \mathrm{c}$ \\
$\mathbf{C + F}$ & $32.31 \mathrm{a}$ & $32.35 \mathrm{a}$ & $33.50 \mathrm{~b}$ & $32.46 \mathrm{~b}$ & $5.73 \mathrm{ab}$ & $5.75 \mathrm{ab}$ & $58.30 \mathrm{a}$ & $56.71 \mathrm{a}$ \\
\hline
\end{tabular}

* Means within a column having the same letters are not significantly different according to Duncan's Multiple Range Test (DMRT) at 5\% confidence.

Table 2. Effect of application method and level of plant growth regulator on fresh and dry weight of leaves and roots of Ficus deltoidea Jack. plant during 2012 and 2013 seasons.

\begin{tabular}{lccccccccc}
\hline \multicolumn{1}{c}{$\begin{array}{c}\text { Application method } \\
\text { and level }\left(\mathbf{c m}^{\mathbf{3}} / \mathbf{l}\right)\end{array}$} & \multicolumn{3}{c}{ Leavesh weight (g) } & \multicolumn{2}{c}{ Roots } & \multicolumn{4}{c}{ Deaves weight (g) } \\
& $\mathbf{2 0 1 2}$ & $\mathbf{2 0 1 3}$ & $\mathbf{2 0 1 2}$ & $\mathbf{2 0 1 3}$ & $\mathbf{2 0 1 2}$ & $\mathbf{2 0 1 3}$ & $\mathbf{2 0 1 2}$ & $\mathbf{2 0 1 3}$ \\
\hline Control & $15.10 \mathrm{e}$ & $15.56 \mathrm{e}$ & $5.80 \mathrm{f}$ & $6.21 \mathrm{ef}$ & $8.20 \mathrm{f}$ & $8.24 \mathrm{e}$ & $1.63 \mathrm{c}$ & $1.69 \mathrm{c}$ \\
Foliar spray at 0.25 (A) & $25.50 \mathrm{~b}$ & $25.60 \mathrm{~b}$ & $11.76 \mathrm{~d}$ & $13.70 \mathrm{c}$ & $12.93 \mathrm{c}$ & $13.00 \mathrm{c}$ & $2.17 \mathrm{~b}$ & $2.20 \mathrm{bc}$ \\
Foliar spray at 0.50 (B) & $22.71 \mathrm{c}$ & $22.83 \mathrm{c}$ & $12.15 \mathrm{~d}$ & $11.89 \mathrm{~d}$ & $15.00 \mathrm{~b}$ & $15.50 \mathrm{~b}$ & $2.60 \mathrm{~b}$ & $2.91 \mathrm{~b}$ \\
Foliar spray at 1.00 (C) & $18.49 \mathrm{~d}$ & $18.50 \mathrm{~d}$ & $8.36 \mathrm{e}$ & $6.55 \mathrm{e}$ & $9.81 \mathrm{e}$ & $10.81 \mathrm{~d}$ & $1.45 \mathrm{c}$ & $1.33 \mathrm{c}$ \\
Soil drench at 0.25 (D) & $25.20 \mathrm{~b}$ & $25.30 \mathrm{~b}$ & $6.30 \mathrm{f}$ & $6.89 \mathrm{e}$ & $11.20 \mathrm{~d}$ & $10.90 \mathrm{~d}$ & $2.60 \mathrm{~b}$ & $2.67 \mathrm{~b}$ \\
Soil drench at 0.50 (E) & $21.60 \mathrm{~cd}$ & $21.90 \mathrm{c}$ & $6.50 \mathrm{f}$ & $6.60 \mathrm{e}$ & $11.80 \mathrm{~d}$ & $11.10 \mathrm{~cd}$ & $1.42 \mathrm{c}$ & $1.60 \mathrm{c}$ \\
Soil drench at 1.00 (F) & $17.92 \mathrm{~d}$ & $18.87 \mathrm{~d}$ & $5.21 \mathrm{f}$ & $5.20 \mathrm{f}$ & $9.10 \mathrm{e}$ & $9.50 \mathrm{~d}$ & $1.30 \mathrm{c}$ & $1.30 \mathrm{c}$ \\
A+D & $32.10 \mathrm{a}$ & $32.00 \mathrm{a}$ & $19.60 \mathrm{~b}$ & $19.50 \mathrm{a}$ & $17.50 \mathrm{ab}$ & $15.78 \mathrm{~b}$ & $6.41 \mathrm{a}$ & $5.27 \mathrm{a}$ \\
B+E & $29.63 \mathrm{ab}$ & $29.90 \mathrm{ab}$ & $16.24 \mathrm{c}$ & $16.40 \mathrm{~b}$ & $15.11 \mathrm{~b}$ & $14.88 \mathrm{bc}$ & $6.60 \mathrm{a}$ & $5.94 \mathrm{a}$ \\
$\mathbf{C + F}$ & $31.60 \mathrm{a}$ & $31.80 \mathrm{a}$ & $22.90 \mathrm{a}$ & $19.97 \mathrm{a}$ & $20.40 \mathrm{a}$ & $19.82 \mathrm{a}$ & $5.95 \mathrm{a}$ & $5.33 \mathrm{a}$ \\
\hline
\end{tabular}

* Means within a column having the same letters are not significantly different according to Duncan's Multiple Range Test (DMRT) at 5\% confidence.

Spraying the foliage at the low and medium levels $\left(0.25\right.$ and $0.50 \mathrm{~cm}^{3} / 1$, consecutively) gave, to some extent better results than the high level $\left(1.00 \mathrm{~cm}^{3} / 1\right)$ with few exceptions, while that was true for soil drenching method when Na- nitrophenolate was drenched at the low rate $\left(0.25 \mathrm{~cm}^{3} / 1\right)$ that gave higher means in most cases of both seasons comparing with the medium and high rates. Combining between the two methods of application caused an additional improvement in growth of plants, with the superiority of foliar spray + soil drench combined treatment at $1.00 \mathrm{~cm}^{3} / 1$ for each, which recorded the utmost high averages in most instances of the two seasons. This may 
be reasonable because of plants absorption of greater amount of Na- nitrophenolates solution by both leaves and roots.

Furthermore, the active ingredients of nitrophenolates stimulated plant growth by altering the activitiy of specific antioxidant enzymes, such as superoxide dismutase, catalase and peroxidase (Djanaguiraman et al., 2004). These antioxidant enzymes are involved in the scavenging of reactive oxygen species (ROS), such as hydrogen peroxide $\left(\mathrm{H}_{2} \mathrm{O}_{2}\right)$, hydroxyl $\left(\mathrm{OH}^{-}\right)$and singlet oxygen $\left(\mathrm{O}_{2}^{-}\right)$(Shanker et al.,2004). The ROS are able to attack polysaccharides, proteins and nucleic acids (Matysik et al., 2002). Oxidative stress can occur when more ROS are produced than are metabolized (Dhindsa et al., 1981), so the ability to ameliorate or lessen the impact of ROS on the physiology and subsequent growth and yield of the crop species by nitrophenolates is a desirable target. Besides, Djanaguiraman et al. (2004) noted the nitrophenolates under many trade names were registered for pesticide use in cotton (Gossypium hirsutum), rice (Oryza sativa) and soybean (Glycine max) and as a protein transport enhancer in cotton.
The previous findings are in well accordance with those of Gornik and Grzesik (2002) on China aster, Xiao-yue (2008) on Camellia oleifera, Jadhav et al. (1990) on Pearl millet, Singh et al. (2010) on cotton and Zhanga et al. (2010) on alfalfa.

\section{2- Chemical composition:}

As shown in Table (3), it can be summarized that leaf content of chlorophyll $\mathrm{a}, \mathrm{b}$ and carotenoids (mg/g f.w.), the percentages of $\mathrm{N}, \mathrm{P}$ and $\mathrm{K}$, as well as Fe, $\mathrm{Zn}$ and $\mathrm{Mn}(\mathrm{mg} / 100 \mathrm{~g}$ d.w.) were increased as a result of spraying the foliage or drenching the soil with Na-nitrophenolates at the different levels, with the dominance of combining between spray and drench methods treatment at the high concentration for each, followed by foliar spray treatment at $0.50 \mathrm{~cm}^{3} / 1$ that gave higher content of chlorophyll $\mathrm{a}, \mathrm{b}$ and $\mathrm{K} \%$, as well as closely near content of carotenoids, $\mathrm{Fe}$ and $\mathrm{Mn}$ relative to the dominant combined treatment mentioned above. Foliar spray at $0.25 \mathrm{~cm}^{3} / 1$ and soil drench at either 0.25 or $0.50 \mathrm{~cm}^{3} / 1$ treatments gave higher content of some constituents near to those of the superior combination.

Table 3. Effect of application method and level of plant growth regulator on some active constituents in the leaves of Ficus deltoidea Jack. plant during 2012 and 2013 seasons.

\begin{tabular}{|c|c|c|c|c|c|c|c|c|c|}
\hline \multirow[t]{2}{*}{$\begin{array}{l}\text { Application method } \\
\text { and level }\left(\mathrm{cm}^{3} / \mathrm{l}\right)\end{array}$} & \multicolumn{3}{|c|}{$\begin{array}{c}\text { Pigment content (mg/g } \\
\text { f.w.) }\end{array}$} & \multirow[t]{2}{*}{ N (\%) } & \multirow[t]{2}{*}{ P (\%) } & \multirow[t]{2}{*}{ K (\%) } & \multirow{2}{*}{$\begin{array}{c}\mathrm{Fe} \\
(\mathrm{mg} / 100 \mathrm{~g} \\
\text { d.w.) }\end{array}$} & \multirow{2}{*}{$\begin{array}{c}\mathrm{Zn} \\
(\mathrm{mg} / 100 \mathrm{~g} \\
\text { d.w.) }\end{array}$} & \multirow{2}{*}{$\begin{array}{c}\text { Mn } \\
\text { (mg/100g } \\
\text { d.w.) }\end{array}$} \\
\hline & Ch. a & Ch. b & Carot. & & & & & & \\
\hline Control & 0.93 & 0.81 & 0.67 & & & 1.34 & 2.20 & 0.05 & 11.05 \\
\hline Foliar spray at 0.25 (A) & 1.62 & 0.93 & 0.82 & 1.70 & 0.24 & 1.70 & 2.46 & 0.07 & 13.13 \\
\hline Foliar spray at 0.50 (B) & 3.74 & 1.64 & 1.41 & 1.70 & 0.25 & 1.81 & 2.79 & 0.09 & 19.20 \\
\hline Foliar spray at 1.00 (C) & 1.24 & 1.02 & 1.00 & 1.98 & 0.28 & 1.55 & 2.24 & 0.06 & 14.24 \\
\hline Soil drench at 0.25 (D) & 2.89 & 1.97 & 0.83 & 1.84 & 0.38 & 1.49 & 2.28 & 0.07 & 12.11 \\
\hline Soil drench at 0.50 (E) & 1.68 & 1.05 & 0.98 & 1.70 & 0.28 & 1.72 & 2.83 & 0.09 & 13.06 \\
\hline Soil drench at 1.00 (F) & 1.31 & 1.00 & 0.98 & 1.56 & 0.23 & 1.58 & 2.54 & 0.07 & 11.10 \\
\hline $\mathbf{A}+\mathbf{D}$ & 2.32 & 2.17 & 1.65 & 1.70 & 0.29 & 1.58 & 2.70 & 0.09 & 14.00 \\
\hline $\mathbf{B}+\mathbf{E}$ & 1.53 & 1.45 & 1.39 & 1.84 & 0.36 & 1.64 & 2.81 & 0.09 & 14.07 \\
\hline $\mathbf{C}+\mathbf{F}$ & 2.48 & 2.05 & 1.69 & 1.90 & 0.39 & 1.72 & 3.19 & 0.17 & 19.33 \\
\hline
\end{tabular}


This may indicate the role of nitrophenolates in increasing assimilating capacity, cell juice activity and absorbing more water and minerals. Djanaguiraman et al. (2004) mentioned that nitrophenolates act as a protein transport enhancer in cotton.

Analogous observations were also obtained by Sharma et al. (1990) on soybean, Bynum et al. (2007) and Gencsoylu (2009) on cotton and Cai-lian et al.(2010) on soybean.

According to the previous results, it can be advised to apply nitrophenolate commercial product to mistletoe fig plant, monthly for 5 repeats as a foliar spray and soil drench at the rate of $1.00 \mathrm{~cm}^{3} / 1$ for each method to get better growth performance.

\section{ACKNOWLEDGEMENT}

The authors wish to express their sincere gratitude to Prof. Dr. Sayed M. Shahin, Head Researches Emeritus, Botanical Gardens. Res. Dept., Hort. Res. Inst., A.R.C. for his help during preparing the manuscript.

\section{REFERENCES}

A.O.A.C. (1995). Official Methods of Analysis of the Association of Analytical Chemists, $14^{\text {th. }}$ Ed., Benjamin Franklin, Washington DC.

Bynum, J.B.; Cothren, J.T.; Lemon, R.G.; Fromme, D.D. and Boman, R.K. (2007). Field evaluation of nitrophenolate plant growth regulator (Chaperone) for the effect on cotton lint yield. J. Cotton Sci., 11:20-25.

Cai-lian, Y.; Bo, L.; Hong, Y.; Ying, Y. and Xian-long, P. (2010). Effects of sodium nitrophenolate and its composition on germination of soybean seeds. Soybean Science, 24:10-16.

Dhindsa, R.S.; Plumb-Dhindras, P.L. and Thrope, T.A. (1981). Leaf senescence: Correlated with increased levels of membrane permeability \& lipid peroxidation and decreased levels of superoxide dismutase \& catalase. J. Exp. Bot., 126:93-101.

Djanaguiraman, M.; Devi, D.; Sheeba, J.; Bangarusamy, U. and Babu, R. (2004). Effect of oxidative stress on abscission of tomato fruits and its regulation by nitrophenols. Trop. Agric. Res., 16:2536.

Duncan, D.B. (1955). Multiple range and multiple F-tests. J.Biometrics, 11:1-42.

Gencsoylu, I. (2009). Effect of plant growth regulators on agronomic characteristics, lint quality, pests and predarors in cotton. J. Plant Growth Regul., 28:147-153.

Gornik, K. and Grzesik, M. (2002). Effect of Asahi SL on China aster "Aleksand" seed yield, germination and some metabolic events. Acta Physial. Plantarum, 24(4): 379-383.

Huxley, A.; Griffiths, M. and Levy, M. (1992). The New Royal Hort. Society Dictionary of Gardening. The Stockton Press, 257 Park Avenue South, New York, NY 10010,USA, vol. 2, 747 pp.

Jadhav, A.S.; Shaikh, A.A.; Shinde, A.B. and Harinarayana, G. (1990). Effects of growth hormones, biofertilizer and micronutrients on the yield of pearl millet. J. Maharashtra Agric. Univ., 15(2):39-45.

Matysik, J.; Alia, A.; Bhalu, B. and Mohanty, P. (2002). Molecular mechanisms of quenching of reactive oxygen speciec by proline under stress in plants. Curr. Sci., 821:525-532.

Mead, R.; Curnow, R.N. and Harted, A.M. (1993). Statistical Methods in Agriculture and Experimental Biology. $2^{\text {nd. }}$ Ed., Chapman \& Hall Ltd., London, 335 pp.

Ogorek, R.; Plaskowska, E. and Skrobiszewski, A. (2011). The effect of Asahi SL biosimulater on the growth of selected species of Fusarium on different culture media. Phytopathologia, 62:4955 . 
Saric, M.; Kastrori, R.; Curic, R.; Cupina, T. and Geric, I. (1976). Chlorophyll Determination. Univ. U Noven Sadu Parktikum is Fiziologize Anjiga , 215 pp.

SAS Institue (1994). SAS/STAT user's Guide: Statistics, Vers. 6.04, $4^{\text {th. }}$ Ed., SAS Institute Inc., Cary, N.C., USA.

Shanker, A.K.; Djanaguiraman, M.; Sudhagar, R.; Chandrasheker, C.N. and Pathmanabhan, G. (2004). Differential antioxidative response of ascorbate glutathione pathway enzymes \& metabolites to chromium speciation stress in green gram (Vigna radiatd L.) roots. Plant Sci.,166:1305-1319.

Sharma, R.; Singh, G.; Ganeshan, K.P.; Kaur, G. and Raheja, R.K. (1990). Yield improvement in soybean by foliar application of some commercial growth regulators. J. Indian Agriculturist, 34 (2): 79-82.

Singh, G.; Kaur, G. and Raheja, R.K. (2010). Nitrophenolates spray can alter boll in cotton through enhanced peroxidase activity and increased ascorbate and phenolics levels. J.Plant Physial., 167(1): $1-9$.

Xiao-yue, C. (2008). Field test on application of Na-ortho-nitrophenolate + Na-para-nitrophenolate $+\mathrm{Na}-5-$ nitronuacolate on Camellia oleifera. Journal of Fujian Forestry Science and Technology, 79(4):406-410.

Zhanga, T.; Wanga, X.; Wanga, Y.; Hana, J.; Maoa, P. and Majerusb, M. (2010). Plant growth regulators effects on balancing vegetative and reproductive phases in alfaffa seed yield. Agronomy J., 101 (5): 1139-1145.

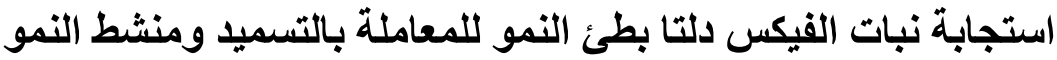

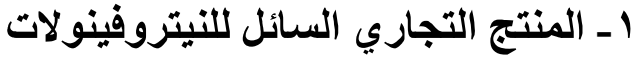

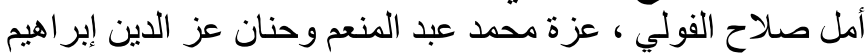

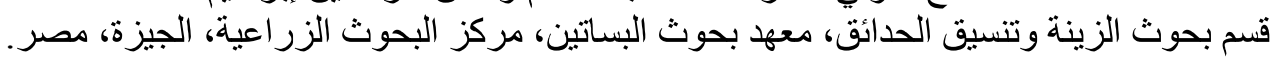

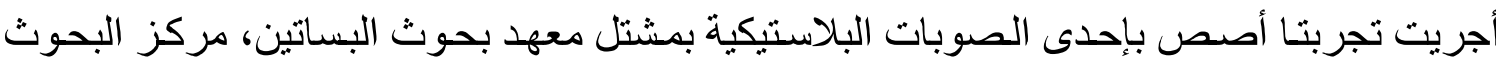

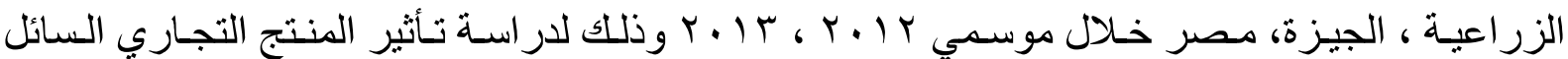

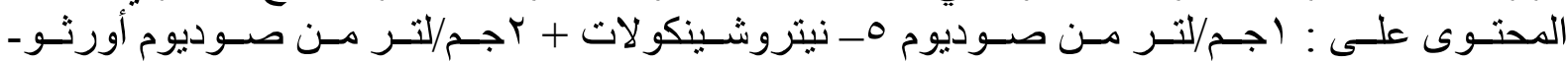

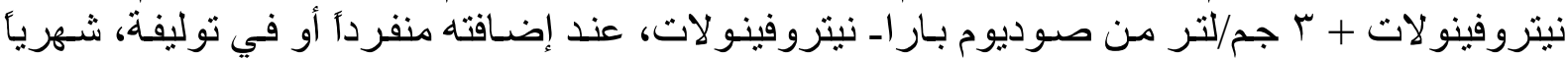

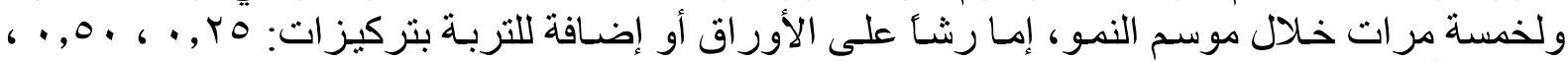

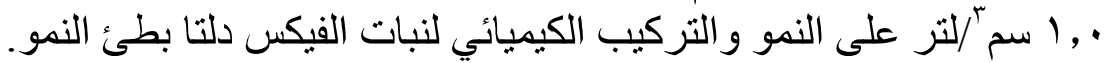

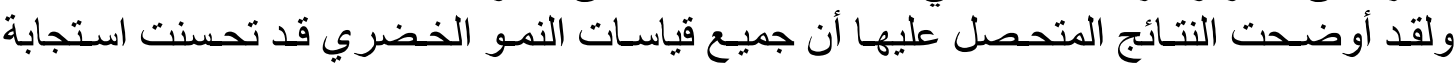

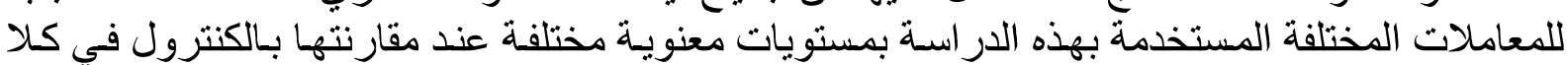

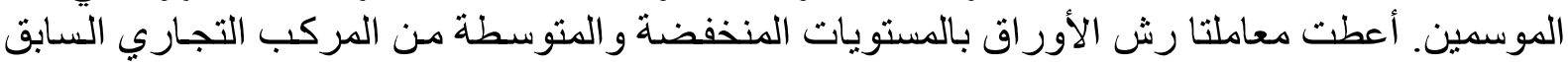

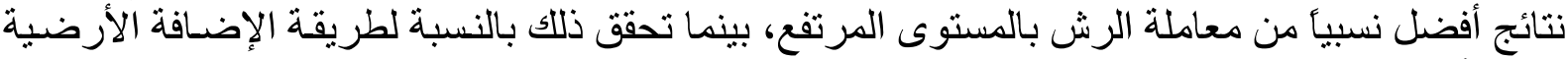

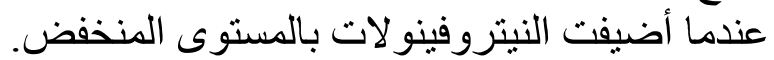

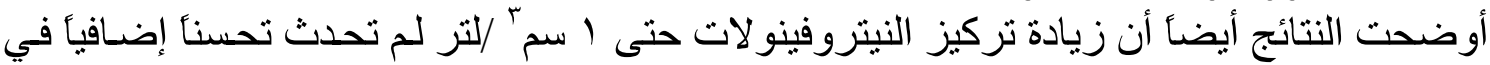

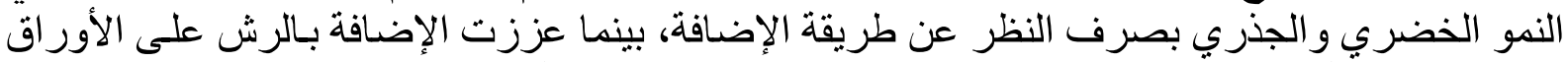

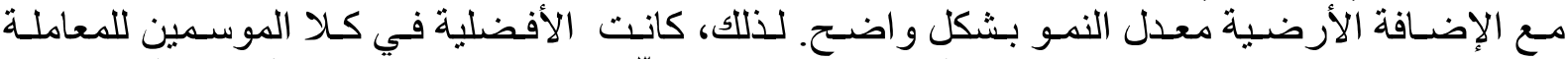

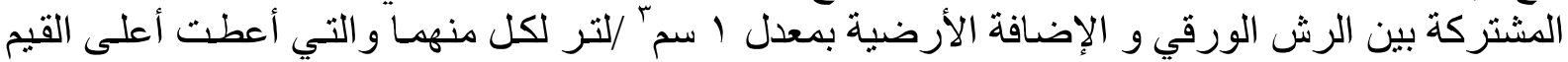

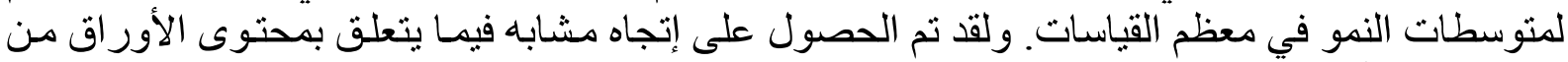

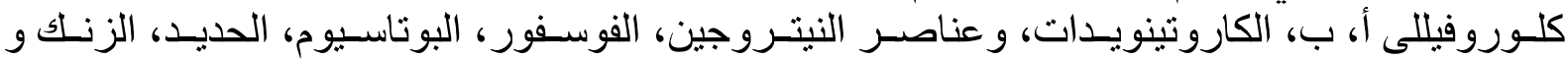




\section{Amal S. El-Fouly et al.}

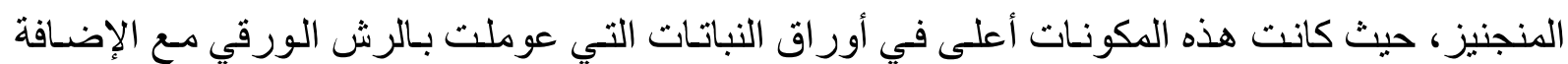

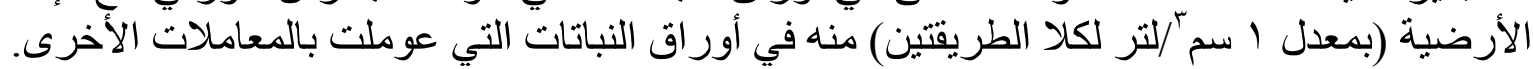

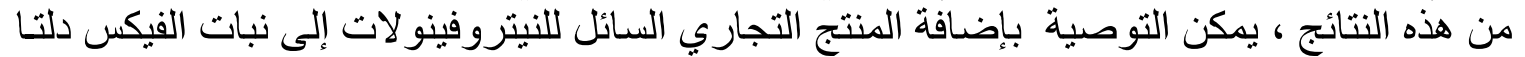

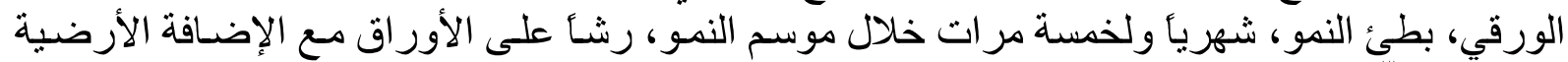

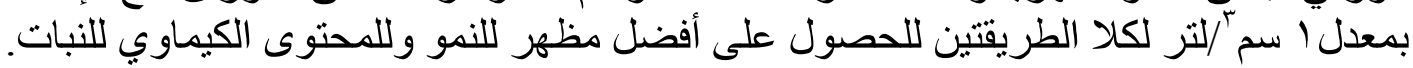

